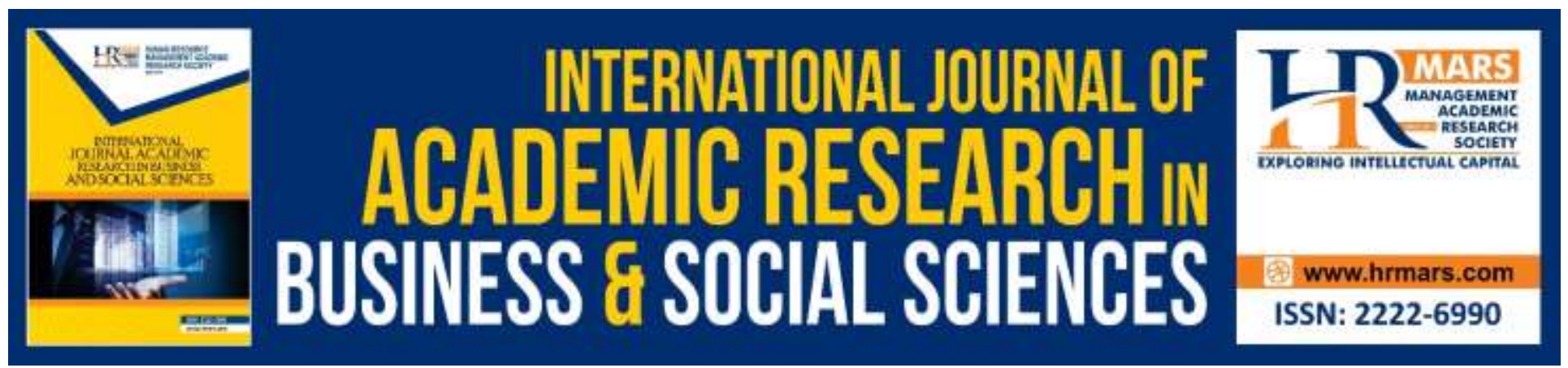

\title{
Issues and Challenges of Oil Palm Cooperatives towards Greater Sustainability: A Proposal of Conceptual Framework
}

\section{Zaifalaila Zakaria, Abdul Rahman Abdul Rahim and Zaki Aman}

To Link this Article: http://dx.doi.org/10.6007/IJARBSS/v10-i1/6806

DOI:10.6007/IJARBSS/v10-i1/6806

Received: 01 December 2019 Revised: 21 December 2019, Accepted: 01 January 2020

Published Online: 09 January 2020

In-Text Citation: (Zakaria et al., 2020)

To Cite this Article: Zakaria, Z., Rahim, A. R. A., \& Aman, Z. (2020). Issues and Challenges of Oil Palm Cooperatives towards Greater Sustainability: A Proposal of Conceptual Framework. International Journal of Academic Research in Business and Social Sciences, 10(1), 46-69.

Copyright: (C) 2020 The Author(s)

Published by Human Resource Management Academic Research Society (www.hrmars.com)

This article is published under the Creative Commons Attribution (CC BY 4.0) license. Anyone may reproduce, distribute, translate and create derivative works of this article (for both commercial and non-commercial purposes), subject to full attribution to the original publication and authors. The full terms of this license may be seen

at: http://creativecommons.org/licences/by/4.0/legalcode

Vol. 10, No. 1, 2020, Pg. 46 - 69

Full Terms \& Conditions of access and use can be found at http://hrmars.com/index.php/pages/detail/publication-ethics 


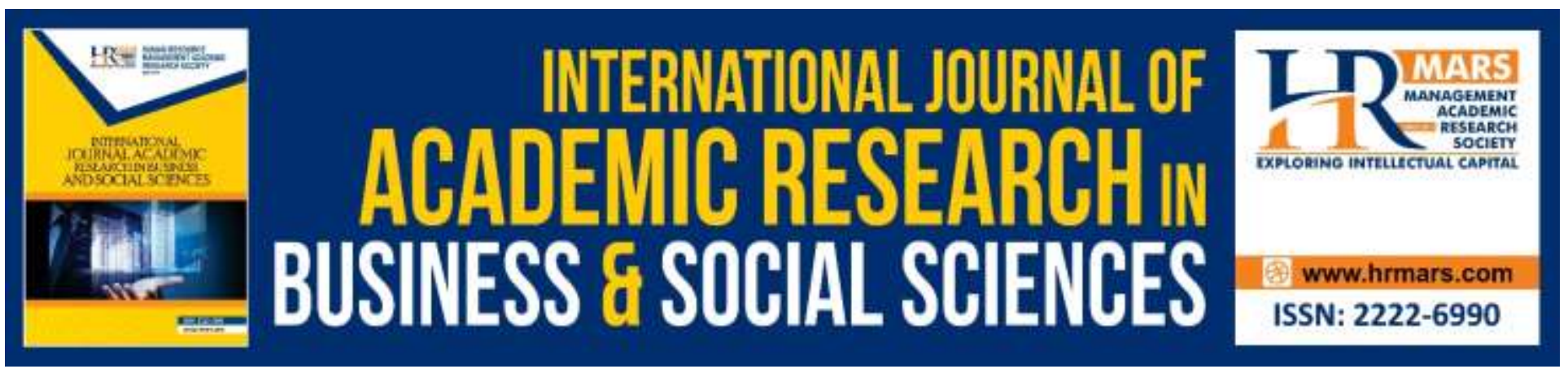

\title{
Issues and Challenges of Oil Palm Cooperatives towards Greater Sustainability: A Proposal of Conceptual Framework
}

\author{
Zaifalaila Zakaria ${ }^{1 *}$, Abdul Rahman Abdul Rahim² and Zaki Aman ${ }^{3}$ \\ ${ }^{1}$ Faculty of Business and Management, Universiti Teknologi MARA, Shah Alam, Malaysia, ${ }^{2}$ Arshad \\ Ayub Graduate Business School, Universiti Teknologi MARA, Shah Alam, Malaysia, ${ }^{3}$ Malaysian Palm \\ Oil Board, Bangi, Malaysia \\ Email: zaifalaila@outlook.my
}

\begin{abstract}
In the cooperative sector, the notion of sustainability is not new as it is being regarded as changemaker that plays an essential role in implementing Sustainable Development Goals by 2030. However, in most cooperative studies, the issues of sustainability, namely climate change, economic uncertainties and social inclusivity are neglected, even though they are often at the crux of global trends. Indeed, there is a crucial need to integrate social, economic and environmental dimensions into the concept and practice of both, sustainability and cooperative sector simultaneously. Given the oil palm cooperatives are among the essential players in the palm oil industry, the potential of cooperatives to engage in sustainability is underestimated and limited research has examined their sustainability-oriented practices (SOP) implementation. However, the complexity and multidimensional sustainability issues have negatively alleged upon the palm oil industry, such as deforestation, transboundary haze, loss of biodiversity and the poor wellbeing of smallholders and plantation workers. These sustainability issues, consequently, motivate this study to focus on the oil palm cooperatives which remains crucial and relevant as Malaysia's socio-economic contributor, albeit the negative allegations from certain quarters. Thus, the aim of this study is to initiate a discourse about SOP in the oil palm cooperatives, primarily comprised of independent smallholding oil palm growers. The outcome of this study is to suggest a conceptual framework which will motivate the smallholders to implement SOP, that ultimately distinguishes Malaysia as the world's leading sustainable palm oil producer. The present study, therefore, contributes to the literature on sustainability and cooperatives by recommending a conceptual framework towards greater sustainability and exceptional performance of the oil palm cooperatives in particular.
\end{abstract}

Keywords: Oil Palm Cooperatives, Sustainability-Oriented Practices, Palm Oil Industry, Cooperative Performance and Oil Palm Sustainability. 


\section{Introduction}

The historical and evolution of the cooperatives theory can be traced back in 1764 with the formation of Fenwick Weavers' Society from Scotland (ICA, 2018b). Cooperative is widely recognised as a democratically controlled and voluntarily joint member-owned-and-governed business (ICA, 2018a). Through self-help efforts, while prioritising the general welfare and inclusivity of the community, cooperative as argued by many (Berry \& Bell, 2018; Cheney et al., 2014; Dale et al., 2013; Grashuis \& Su, 2019; ILO and ICA, 2015; Kyazze et al., 2017; UN, 2017) is able to generate employment and income, reduce poverty as well as foster social integration. Across the globe, cooperatives have contributed almost 7\% of the world's gross domestic product (GDP) (CICOPA, 2017; UN, 2017). In this regard, the global communities are convinced in the roles of cooperatives that enhanced the socioeconomic development and well-being of the people regardless of their socio-economic backgrounds.

In September 2015, the cooperative sector was explicitly recognised as a critical sector to achieve Sustainable Development Goals (SDG) by 2030 (Abdul Aris et al., 2018; Esim, 2017; UN, 2017). The United Nations (UN) is right to put its hope in the cooperative as a critical player of sustainability agenda given that $12 \%$ of world population is co-operator accounted of 3 million cooperatives establishment while providing more than 100 million jobs or $10 \%$ of the employed population globally, as evidenced from the World Cooperative Monitor data (ICA, 2019). The sustainability agenda has compelled businesses, including cooperatives, to adopt practices that balance economic, social and environmental dimensions.

Although cooperative is well-positioned in sustainability agenda, Herbert et al. (2016) implied that the vast majority of cooperatives do not prepare any sustainability reports, albeit the growing majority of business organisations have embraced sustainability efforts in their reporting throughout the world (Karlsson et al., 2018; Mura et al., 2018). From the cooperative's perspective, there are plethora of empirical studies across the world as well as in Malaysia context which are explicitly focusing on the membership size, participation, and attitude (Cai et al., 2016; Chagwiza et al., 2016; Jensen-Auvermann et al., 2018; Ma \& Abdulai, 2016; Yacob et al., 2018), cooperative performance (Benos et al., 2018; Giacomini et al., 2017; Grashuis, 2017, 2018; Grashuis \& Su, 2019; Martins \& Lucato, 2018; Castilla-Polo et al., 2018; Sallehhuddin et al., 2017; Shamsuddin et al., 2017; Shamsuddin et al., 2018), and cooperative governance (Berry \& Bell, 2018; Birchall, 2017; Errasti et al., 2017; Kyazze et al., 2017; Nurhazani et al., 2016; Saleh \& Hamzah, 2017). Due to the attention on sustainability indicators for cooperative is limited in comparison to typical profit-oriented businesses, Abdul Aris et al. (2018) corroborated the indicators for sustainability as a cooperative's performance measurement in Malaysia. Similarly, through mixed research method, Riva and Garavaglia (2016) affirmed that the sustainability of cooperatives not just relates to economic indicators, such as employment, income and financial performance, but also to the social, cultural and political dimension. However, Mathuva and Kiweu (2016) revealed the negative association between social and environmental disclosure on the financial performance of cooperatives in Kenya. Tuominen et al. (2017) affirmed the crucial role of cooperatives in corporate social responsibility (CSR) activities which are overlapping and conceptually interchangeable with sustainability dimensions. It is thus observed that cooperative's principles have guided the cooperatives to become community-oriented 
and socially responsible entities in line with the implementation of sustainability-oriented practices (SOP) that differ from public listed and profit-oriented businesses.

Along this line, the focus to research on sustainability in the context of cooperative is in dearth in terms of its causality with performance, and lack of integrated manners to address the economic, social and environmental issues simultaneously. With this regard, it is decisively crucial to design better sustainability measures in formulating new strategies and policy for the cooperatives sector, as Abdul Aris et al. (2018) propose. Although cooperative is by nature a sustainable organisation which has proven to be resilient and relevant in addressing present global challenges (Benos et al., 2018), the limited attention on sustainability in cooperatives has provided an opportunity to examine on this matter extensively. Given the cooperative performance and sustainability practices have been separately researched, there is a gap in knowledge on the combined effect of SOP on cooperative performance building upon preceding discussion. In other words, the need for conceptual consolidation of research on the issue of cooperative's sustainability and performance measure remains pertinent (Abdul Aris et al., 2018; Benos et al., 2018; Grashuis \& Su, 2019). This present study, thus, will fulfil this gap by proposing a conceptual framework towards greater sustainability that results in exceptional cooperative performance.

In the context of the palm oil industry, its contribution to Malaysian socio-economic development in helping to end poverty by improving the income of smallholders and reducing ruralurban disparities through the provision of comprehensive resettlement especially in the rural areas is indisputable (Cramb \& McCarthy, 2017; Nambiappan et al., 2018). In this regard, the government urges the independent smallholders to establish cooperative which has a two-pronged purpose as an instrument that will enable them to produce sustainable palm oil while increasing their income in pursuing the whole socio-economic betterment. The first purpose is to produce sustainable oil palm in line with Malaysia's full commitment to the sustainability palm oil certification or known as Malaysian Sustainable Palm Oil (MSPO) by 2020 as reiterated by Malaysian Prime Minister Tun Dr Mahathir Mohamad during the $73^{\text {rd }}$ United Nations General Assembly (UNGA) in 2018 (PMO, 2018). Thus far, only $19 \%$ or 1.09 million hectares of the 5.85 million hectares of Malaysian oil palm plantations is sustainability certified, reflecting the difficulties of the oil palm growers especially the independent smallholders in producing sustainable palm oil (Kumaran, 2019; MPOCC, 2019). As corroborated by Hutabarat et al. (2019), certification gap exists among the oil palm independent smallholders due to limited economies of scale, agronomic constraints, and institutional barriers. The second purpose is to increase the smallholders' revenue by removing the middlemen, who will typically charge an extra fee on the sale price of oil palm fresh fruit bunches (FFB) (Hutabarat et al., 2018). It concurs that the removal of middleman will help the smallholders who are still regarded as the world's most deprived farmers be able to sustain their income despite fluctuations of palm oil prices that may affect their ability to meet basic needs, particularly in a rural region.

Thus, this conceptual study will shed some lights in finding answers to the alarming challenges regarding oil palm cooperatives in Malaysia. In addition, Malaysia's aim to achieve oil palm plantation areas that sustainably certified has yet to be successful (Kumaran, 2019). In this connection, it is upmost important to examine and explore the conceptualisations of SOP on oil palm cooperatives performance. Building upon above-mentioned reasoning, the objective of this study is to propose the SOP framework by conceptualising the SOP in oil palm cooperative that ultimately leads to its higher 
performance. This study commences with a review of issues and challenges of oil palm cooperatives. The next section elucidates further on the literature about the SOP concept, cooperative performance concept, the approach and method of this study, the discussion regarding SOP and cooperative performance in the context of oil palm cooperatives, the proposal of SOP conceptual framework and the theory that underpins the framework. This study concludes by considering the theoretical and practical implications of the conceptual framework, identify future research and drawing a conclusion.

\section{Research Objectives}

1. To explore the issues and challenges of the oil palm cooperatives towards greater sustainability.

2. To propose a SOP conceptual framework that improve performance of the oil palm cooperatives.

\section{The Issues and Challenges of Oil Palm Cooperatives in Malaysia}

In the case of the Malaysian palm oil industry, it is dominated by three key players, namely private companies, organised smallholders, and independent smallholders. Malaysian oil palm smallholders can be distinguished as organised smallholders and independent smallholders. The organised smallholders (under supervision of federal, state and other government's agency responsible to smallholding schemes, such as FELDA, FELCRA and RISDA) and independent smallholders who are defined as oil palm grower that owned land of less than 40.46 hectares or 100 acres. The palm oil industry indeed is pivotal in Malaysia for the main reason that it contributes to job creation and enhanced the well-being and living quality of people, especially in rural areas. As of December 2018, Ministry of Primary Industries (MPI, 2019) implied that almost 670,000 smallholders, who make up nearly $40 \%$ or $2,280,805$ hectares of the total oil palm planted areas depended on the oil palm plantation for their livelihood, while the other $60 \%$ or $3,568,525$ hectares are owned by the private estates as revealed in Table 1.

However, the independent smallholding only achieved certified area of slightly more than $1 \%$ of the total Malaysian independent smallholding (Kumaran, 2019). While, organised smallholding recorded a higher certified area of 105,751 hectares or $8.1 \%$ and private estates recorded the highest certified area which is 971,732 hectares or $27.2 \%$ of the total private estates in Malaysia (Kumaran, 2019). As of July 2018, the total of MSPO certified oil palm planted area is $1,089,796$ hectares, as illustrated in Table 1. Despite provision of available financial assistance by the Malaysian government that covers MSPO auditing fees to smallholders, growers and processing facilities, the full MSPO certification for all oil palm plantation has yet to be successfully implemented.

Table 1: Oil Palm Planted Areas by Categories in 2018 
INTERNATIONAL JOURNAL OF ACADEMIC RESEARCH IN BUSINESS AND SOCIAL SCIENCES Vol. 10, No. 1, Jan, 2020, E-ISSN: 2222-6990 @ 2020 HRMARS

\begin{tabular}{|l|l|l|l|l|}
\hline Category & $\begin{array}{l}\text { Areas } \\
\text { (hectares) }\end{array}$ & $\%$ & $\begin{array}{l}\text { MSPO Certified } \\
\text { Areas (hectares) }\end{array}$ & \% \\
\hline Private Estates & $3,568,525$ & 61.0 & 971,732 & 27.2 \\
\hline Independent smallholders & 979,892 & 16.7 & 12,312 & 1.3 \\
\hline $\begin{array}{l}\text { Organised smallholders } \\
\text { (Federal, state and other government } \\
\text { schemes) }\end{array}$ & $1,300,913$ & 22.2 & 105,751 & 8.1 \\
\hline Total Planted Areas & $5,849,330$ & 100 & $1,089,796$ & 19 \\
\hline
\end{tabular}

Source: MPI (2019), Kumaran (2019)

As evidenced from the statistic provided in Table 1, there are difficulties and challenges for the smallholders to achieve the sustainability certification which leads to higher yield and to achieve the ambitious target for the implementation of mandatory sustainability certification, MSPO for oil palm plantations by 2020. Even though there are almost 670,000 independent smallholders in Malaysia, they are facing substantial challenges to produce sustainable palm oil due to the insufficient technical and financial support, remoteness of smallholders from farm knowledge and training infrastructure, inability to get affordable seedlings and fertilisers, poor plantation management, and reliance on the dealers or middleman to sell FFB (Ador et al., 2016; Martens et al., 2019; Nesadurai, 2019; MPI, 2019).

However, Tayleur et al. (2018) argued that the sustainability certification standard for crop commodity is claimed as having high barriers to the smallholders and deemed a failure to reach the very most deprived areas based upon spatial data on certified crop commodity producer. Given the substantial challenges faced by the independent smallholders to produce sustainable palm oil, the government established the oil palm cooperatives called "Sustainable Oil Palm Growers Cooperative (KPSM)" as a special purpose vehicle operating and representing these independent smallholders activities since the year 2009 (Ador et al., 2016; Shaufique, 2017). This initiative, thus echoed the same sentiment by Benos et al. (2018) and Masuku et al. (2016) that corroborated the increasing trend of cooperatives establishment has proven that cooperatives are a way of life that continues to be a tradition in finding a solution to the various socio-economic problems related to the community.

Furthermore, the government targets to boost crude palm oil (CPO) yield to six tonnes per hectare by 2020, from 3.2 tonnes per hectare in 2018 (MPI, 2019; PMO, 2018). Given the difficulties in meeting the CPO yield target of six tonnes per hectare by 2020 due to general fundamental factors such as soil and weather conditions and labour shortage, the yield is expected to be increased through the implementation of sustainability certification (Ador et al., 2016; Kumaran, 2019). Realising this target, the oil palm cooperatives which majority comprised of independent smallholders must improve their capabilities to achieve full production of sustainability certified palm oil by 2020 . The struggle of oil palm cooperatives escalates given their participation in the whole supply chain of the palm oil industry is far behind compared to the privately-owned estates (Kushairi et al., 2018; Nambiappan et al., 2018). In comparison, most of the plantation activities in the cooperatives are only focusing on the upstream supply chain that mainly caters on the management of the plantation area such as plant nursery, land preparation, FFB harvesting, loose fruit collection, fruits evacuation and transportation to the mills. On the contrary, the private palm oil plantation 
estates are actively involved with sufficient resource to implement the sustainable measure in their business operations throughout the whole value chain, which consists of upstream, midstream and downstream segment (Kushairi et al., 2018; Nambiappan et al., 2018).

Even though the performance, capabilities and resources of oil palm cooperatives are lagging compared to the private estates which belong to major corporations, cooperatives formation is pivotal as an instrument for creating an economic opportunity that will enable the oil palm smallholders to achieve sustainable oil palm production, to increase their income, and gain better livelihood. The disparity will be reduced through the adaptation of SOP framework, which is essential for the whole industry without neglecting the need for smallholders to pursuit greater sustainability through the cooperative formation. Due to these challenges, oil palm cooperatives must respond by adopting SOP, which can lead to their significant performance.

\section{Literature Review}

This study refers to the existing literature in deliberating broad and multidimensional construct of SOP and business performance, especially in cooperatives. This is then followed by the development of the conceptual framework.

\section{Sustainability-oriented Practices (SOP) Concept}

Brundtland (1987) helped to ignite public and private awareness when she first defined sustainable development as "development that meets the needs of the present without compromising the ability of future generations to meet their own needs" which later was widely cited. After a decade, Elkington (1998) coined the sustainable development phenomenon as the Triple Bottom Line (TBL) approaches or 3Ps (People, Planet and Profit) that emphasise the needs of long-term balance of three dimensions between people (equality in society), the planet (the quality of the environment) and profit (a prosperous economy). However, Laurell et al. (2018) argued concerning the confrontation to balance three sustainability dimensions, namely social, economic and environmental and to consider the level at which the balance is struck. Parallel with this concern, conflicting relationships between economic, social and environmental dimensions remains pertinent which characterised business environment currently (Göran Svensson et al., 2018).

Through a questionnaire survey consisting of the largest businesses in Sweden, Laurell et al. (2018) validated and extend the framework for business sustainability which able to practically monitor and assess businesses' efforts towards sustainability. Furthermore, the phrases sustainability, CSR, corporate social performance, going green initiatives, 3Ps, and the TBL approach, are all referring to organisations enhancement efforts for their long-term economic, social, and environmental performance and not to focus solely on economic gains only (Galpin et al., 2015). Thus, sustainability has become the strategic imperative of the new millennium to be continuously considered by all types of business entities in order to overcome the foreseeable and critical challenges associated with sustainable development.

In this connection, a business must be able to evolve and adapt to encounter those conundrums related to sustainable development (for example; urbanisation, population ageing, political and technology disruption, and climate change). Recently, businesses are increasing their SOP as urged by their stakeholders to consider it as a part of a business's dynamic capabilities. 
Realising the need to resolve the conflict between the three dimensions namely economic prosperity, environmental quality and social equity is indeed a complicated task because to transform the organisation to follow the sustainability agenda, management needs systematic and holistic thinking that will transpire in business activities and its organisation (Laurell et al., 2018). Orientation towards sustainability practices simultaneously is crucial by focusing on the outcome of social, economic and environmental dimensions in maintaining and improving the profitability of a business (Karlsson et al., 2018; Upward \& Jones, 2016).

In line with Porter hypotheses (Porter \& Linde, 1995), businesses are increasingly engaging in the environmental dimension of SOP because not only it is the right thing to do, but also it provides a means to either minimize costs or increase revenues because businesses reducing the inputs they used (Karlsson et al., 2018). Similarly, the environmental dimension of sustainability is significantly more defined and developed in the literature, as Göran Svensson et al., (2018) propose. However, Høgevold et al. (2015) argued that the social dimension of SOP still lacks behind environmental and economic dimensions, although studies that incorporated all three sustainability dimensions are increasing.

Bocken et al. (2014) describe sustainable practices of businesses as efforts that provide substantial positive, which significantly reduced both environmental and societal negative impacts. This effort changes the organisation in creating, delivering, and capturing its value network and propositions. Eriksson and Svensson (2016) postulated that businesses must initiate sustainability practices aggressively, which any step back will lead to anthropogenic climate change causing more people to live below the poverty line. Building upon reasonings by Cantele and Zardini (2018) and Tarmuji et al. (2016), the importance of SOP in business is mounting, given that all types of businesses will also generate reputational gains, build its competitive advantages while enhancing its long-term performance upon their sustainable practices. However, SOP is different, dynamic, open, adaptable, and iterative between industries as contended by Helleno et al. (2017b), Henao et al. (2019), Padin et al. (2016) and Parris and Kates (2003) and Goran Svensson et al. (2016). It was therefore not appropriate to compare various business entities and industries, as their practices, abilities and efforts must be differently oriented. Along these lines of reasoning, it is crucial to precisely examine and consider the most appropriate dimensions of SOP for cooperatives which have dual-pronged social and economic objectives that influence its performance and differ from the typical profitoriented businesses.

The SOP is crucial because it shapes how a business manages can implement sustainability throughout their organisation. For the reason that the importance on the need to balance and integrate all the sustainability dimensions, businesses need to identify SOP which is generating maximum profits, while at the same time does not sacrifice the needs of future generations by managing impacts and risks to the environment and societies. Building upon preceding discussion, it can be summarised that SOP is one of the possible ways to generate positive financial aims or improving the performance of all types of businesses, including cooperative. Given that SOP has three dimensions, namely social, economic and environmental, this study attempts to elucidate each dimension in the oil palm cooperative context as a subject of interest in this study.

\section{Cooperative Performance Concept}


In this section, several studies concerning the performance of the various cooperatives, particularly in the agricultural sector from across the globe, are evaluated and deliberated. In the context of performance in business, it involves multiple activities comprised of product quality improvement, efficiency, effectiveness, productivity, and service capabilities, which lead to sustainable profits growth (Ghalem et al., 2016; Masuku et al., 2016). Grüning (2002) defines performance as the ability of a business to achieve goals, meet its expectations, and is therefore influenced by results in the broader sense, and by the corresponding goal setting. In other words, performance is the result of how management achieve its goals.

Given the unique business model of cooperatives, which is based on the mutual principles and values to meet the demands of their members, indeed cooperatives are required to sustain its performance to conduct their business activities efficiently. Abdul Aris et al. (2018) signified that cooperative is able to maintain its performance based upon financial dimension that includes current ratio, gross profit, net profit, return on assets (ROA), return on sales (ROS), return on equity (ROE), and net tangible asset. Grashuis (2018) examined the interrelationship of the performance in terms of efficiency, productivity, and leverage of the US farmer cooperatives by using quantile regression analysis. It was explicitly concluded that variability in ROE is primarily related to the net operating profit margin, which is a cost-efficiency indicator and exhibit a significant relationship with performance. Therefore, Grashuis (2018) posited that agricultural cooperatives would improve its performance by optimising sales and operating costs accurately, enhancing on bargaining power, product differentiation, as well as economies of scale. Due to aforementioned reasoning, the performance of cooperative is weighted upon cooperative revenue because it is standardized, widely accepted and commonly used in evaluating business performance as Hammad Ahmad Khan et al. (2016) propose.

In line with hypothetical expectations, several empirical shreds of evidence have denoted the relationship between the degree of cooperative product quality and its performance. As being observed in agricultural cooperatives, open-access membership policy and pooling arrangements of their farm products do not lead to high-quality market products which lead to slow development of their own brand (Grashuis, 2017; Kontogeorgos, 2012). Traditionally, this policy has obliged for the cooperatives to accept all member's agricultural products regardless of its quality, which causing the free-rider problem. Nevertheless, better access to newest agricultural technology and knowledge, fertilisers, seeds, machinery, and increment of output demand will improve the member's ability and willingness to enhance the quality of the product of their farm outputs (Grashuis \& Su, 2019).

In the agricultural studies, productivity value generally is calculated by multiplying the quantity of each crop produced per hectare by the farmgate or market price for the produce at household or village level, or whichever data that is available in the datasets (Ragasa \& Mazunda, 2018). In Ethiopia, Chagwiza et al. (2016) assessed the influence of cooperative membership on the productivity of dairy producers measured by milk production, the price per litre of milk, the price per $\mathrm{kg}$ of butter and the share of milk production that is processed at the household level. It was decisively concluded that rural development and food security would be improved, particularly in facilitating technological knowledge transformations and commercialisation through cooperatives as an efficient business institution. 
In tandem with theoretical anticipation, the previous empirical literature on agricultural cooperatives agreed that the price of agricultural products is higher in line with cooperative membership (Grashuis \& Su, 2019). For example, in Finland's livestock sector, Alho (2015) revealed that the farm's prices received by the dairy farmers are more acceptable than the swine farmers. It was suggested that in areas where many buyers operate, an attractive price level might hold because the buyers compete for producers that may also reflect the bargaining power of farmers, and consequently lead to an increment of products prices. In Ethiopia, Wassie et al. (2019) posited that agricultural performance in terms of yield, increased to 1.37 quintal per hectare and member's income improved to 1,804 birr as a result of membership in cooperatives. However, Chagwiza et al. (2016) revealed there was no significant impact of cooperative membership on prices of dairy products in Ethiopia, thus concluded that cooperatives were not able to offer better prices for their members. The results affirmed that membership of commercial vegetable cooperatives has so far had no effect on agricultural incomes or the value or amounts of agricultural inputs. Ofori et al. (2019) echoed similar finding that membership of commercial vegetable cooperatives in Cambodia had no effect on member's income or the value of agricultural inputs in contrast with theoretical anticipation (Grashuis \& Su, 2019).

Building upon preceding discussion and argument, there are four dimensions, namely revenue (Hammad Ahmad Khan et al., 2016), product quality (Grashuis \& Su, 2019), productivity (Chagwiza et al., 2016), and income of cooperative's member (Grashuis \& Su, 2019; Wassie et al., 2019) which are relevant to measure agricultural cooperative performance. Thus, this study uses four dimensions which are revenue, product quality, productivity or yield and income of smallholders to depict the performance of oil palm cooperatives upon the implementation of SOP. The next section elucidates the four dimensions of performance in the context of oil palm cooperatives.

\section{Method}

In this study, exploratory research method is used to review academic literature and Malaysian government annual reports, factsheets and statistics on cooperative sector (Malaysian Cooperative Societies Commission) and palm oil industry (Ministry of Primary Industries Malaysia, Malaysian Palm Oil Board and Malaysian Palm Oil Certification Council) as well as literature on cooperative and sustainability globally. This is an effort to determine the importance of sustainability in the cooperative sector in general and palm oil industry in particular. The literature on cooperatives in Malaysia and globally, especially in the palm oil industry, was examined from related research and academic journals such as Palm Oil Economic and Outlook Seminar, Journal of Oil Palm Research, Journal of Co-operative Organization and Management, International Journal of Sustainable Agricultural Research, United Nations, International Labour Organizations and International Cooperative Alliance, apart from government annual reports, policy documents and conference proceedings.

\section{Discussion on SOP in the Context of Oil Palm Cooperatives}

In this section, the discussion on SOP in the context of oil palm cooperatives is deliberated based on three dimensions of SOP, namely social, economic and environment. Firstly, the social dimension of SOP in this study is weighted on the practices that create and equitably distribute value with intrinsic 
rights, as well as improving societal condition among its members. Contribution of the palm oil industry to Malaysian socio-economic improvement is indisputable. It has eradicated poverty by lifted the income of smallholders and reducing rural-urban disparities through the provision of comprehensive resettlement especially in the rural areas (Cramb \& McCarthy, 2017; Rival \& Levang, 2014; Tayleur et al., 2018). The palm oil industry also provides a source of employment and better livelihood for more than three million people, amongst which are small landowners, labourers, and smallholders (Ministry of Primary Industries, 2018). From the global perspective, this industry has been dominantly recognised in the international edible oil market which has helped to feed billions of world population (Yew, Awang, Manaf, Ramli, \& Nambiappan, 2016). This is evidenced when palm oil accounted for $34.7 \%$ out of 230.08 million tonnes of oils and fats produced globally and occupied $60 \%$ out of 88.04 million tonnes of global oils and fats export in 2018 (MPI, 2019).

In Malaysian oil palm smallholding scheme, Abazue et al. (2015) empirically examined the social sustainability practices in terms of improvement of their social position, CSR implemented by the plantation management to improve the social lives of smallholders, the betterment of their quality of life and health status, the quality of education incentives, and participation in decision making. Abazue et al. (2015) revealed positive and significantly improved social benefits and social status of the smallholders under the management of this land smallholding scheme. Also, the majority of respondents perceived the scheme has contributed to a greater extent in improving their overall health and quality of life. It was concluded that effective management of oil palm plantation would contend with issues related to high unemployment and poverty in the rural area.

On this matter, the social dimension of SOP has adapted from the work by Reverte et al. (2016) and modified to suit the oil palm cooperative's social practices that treated both, its workforce and members interest together. Among the social dimension of SOP that is decisively selected in this conceptual study is to what extent the cooperative committed in improving the quality of lives of the members, consideration to members' interests in decision making, enhancing cohesiveness among its members and encouragement towards social participation regardless of its member's socioeconomic background.

Secondly, the economic dimension of SOP refers to the value that cooperative provides to its members with the intention of the cooperative future business survival (Gao, 2010; Høgevold et al., 2015). This value is reflected through information about the ability of the cooperative to pay its bills, reinvest in the business, and distribute profits to its members. In the case of oil palm cooperative, it has indeed contributed to the local economic system by increasing the income of smallholders, but for the moment, it has limited involvement in the international business and shareholders' investment. Although Malaysia's palm oil contributed to the $30 \%$ of world production, accounted for approximately $4.7 \%$ of Malaysia's GDP component valued at RM55.9 billion and generated 5\% of exports earnings in 2017 (DOSM, 2017; Nambiappan et al., 2018). In Malaysia, empirical evidence by Abazue et al. (2015) revealed that majority of oil palm smallholders have indicated that smallholding plantation scheme had improved their economic sustainability through enhanced employment opportunities and job creation than any other economic activity they previously engaged. Therefore, it concurred that the oil palm smallholders are financially sustainable than they were in their previous jobs. 
Due to this line of reasoning, the economic dimension of SOP in this present study is weighted on to the practices that sustain oil palm cooperative's operation in terms of the recognition as having the best quality for oil palm, fostering business relationship with suppliers, providing complete and accurate information related to oil palm and ensuring a formal procedure for the interaction and dialogue with all the stakeholders consist of cooperative's members, customers, suppliers and authorities. In particular, sustainability certification which is MSPO is relevant to the oil palm quality and standard given the MSPO certification requires auditing by third-party independent Certification Bodies (CB). The audit report is also subjected to peer review process during initial and e-certification audits for oil palm management (Kumaran, 2019). With this regard, four items of the economic dimension within the SOP were also modified to suit the oil palm cooperatives business nature, which is adapted from the work by Reverte et al. (2016).

Thirdly, the environmental dimension of SOP consists of efforts undertaken by cooperative which encompasses minimization of environmental impacts from its plantation, reductions in waste generated, optimisation of by-products such as oil palm trunk for building materials as well as the usage of agricultural modern and environmentally friendly technology, mechanisation and automation in its plantation. The four items to measure the environmental dimension of SOP in oil palm cooperatives were adapted from Reverte et al. (2016). For the reason that oil palm plantation has been linked with the environmental issues, namely deforestation, the loss of biodiversity, wildlife protection, and unexpected hazards such as forest fires and periodic transboundary haze, environmental dimension of SOP that aimed to address these environmental issues are intrinsically considered under this dimension (Abazue et al., 2015; Pye, 2018).

Nowadays, Malaysia has a constraint in terms of new arable land available for palm oil plantation. In 2017, it was estimated that oil palm had cultivated almost $52 \%$ of the total agricultural land (10.94 million hectares) throughout Malaysia (Nambiappan et al., 2018). Over the last century, the palm oil industry has been the bedrock of Malaysia's economy, socio-development, political stability and its ability to innovate has widely acknowledged (MPOC, 2019). As revealed by the data from the Ministry of Primary Industries (2019), in 2010, the oil palm cultivation was 4.8 million hectares, which represents a $20 \%$ increase in 2018 . The minimal growth of oil palm planted area from 2010 till 2018 between $1 \%$ to $3 \%$ is reflecting the consistent government policy to sustain the industry while protecting the natural forest from a massive expansion of oil palm plantation. In the long-run, Malaysia must stop expanding oil palm cultivation because the arable land available in Malaysia is near to the limit. For what is worth, Malaysia needs to fully utilise all the arable land available, especially land owned by the smallholders with the highest yield. Malaysia thus consented to cap oil palm plantations areas at about 6.5 million hectares by 2023 that would pave the way for the local palm oil industry to oust negative perceptions from certain quarters (MPI, 2019).

Furthermore, the current market orientation of palm oil industry is shifting towards sustainability efforts because of the grave concern about the sustainability of palm oil production in many essential export markets, most notably in the EU and US. Due to the issues of sustainability, the non-tariff barriers are being erected against the palm oil-based products. Furthermore, the sustainability action is magnified in other continents when the market access is to be restricted due to the sustainability provision for biofuels in the EU region (Gan \& Li, 2014; Nambiappan et al., 2018). Thus far, the government has instigated ongoing efforts to overcome the negative allegations on a 
sustainable issue associated with the palm oil industry including the mandatory compliance of MSPO certification scheme by 2020 (Ahmad Kushairi, 2017; Kumaran, 2019). On this matter, the most crucial efforts are the adoption of the palatable environmental dimension of SOP which comprises of independent smallholders that lack the financial and technical capacity to apply sustainability practices and obtain certification scheme to its oil palm plantation (Ador et al., 2016; Shaufique, 2017).

Abazue et al. (2015) revealed that the majority of the oil palm smallholders were concerned about ecology destruction. However, they needed to plant and grow oil palm for them to support and care for their dependents which constrained them to avoid plantation practices that would affect the ecology. The environmental practices of sustainability in oil palm smallholding plantation scheme is measured based upon its effort in conservation and protection of species in settlements, the usage of modern technology to address environmental issues, and periodic review of activity that help to reduce environmental impacts. It was concluded that oil palm plantation management must perform a significant role to monitor and periodically review their operations to enhance ecological sustainability as part of efforts towards environment preservation and compliance of palm oil sustainability certifications.

When a cooperative engages in SOP, it may be interpreted to create a reputation and image of sustainability to influence its customers, clients, partners and competitors. Although it does not affect the cooperative financial performance immediately, that can still be satisfying the interests and needs of the members in the long run. In this connection, cooperators must improve their SOP by communicating and reporting their activities. Indeed, the SOP performs well when they can reduce the cooperative's exposure to uncertain risks, more resilience and foster members' participation that lead to its higher performance.

\section{Performance in the Context of Oil Palm Cooperatives}

In the context of oil palm plantations owned by the smallholders, the production cost is high, especially in terms of input materials and transportation charges. In this connection, some smallholders are trying to reduce the costs by using inferior quality input materials that eventually produce low-quality oil palm FFB (Ador et al., 2016). The importance of product quality in the palm oil industry is to affirm and to comply with the aspect of sustainability certification integrating the crucial elements of the planet, profit and people throughout the whole palm oil value chain. Furthermore, the quality of palm oil should not be compromised due to the branding of palm oil as a healthy oil that represents its superior quality to meet the premium pricing specifications globally (Kushairi et al., 2018). As suggested by Grashuis and Su (2019), product quality of agricultural including oil palm will be considered as one of the cooperative performance dimensions in tandem with the price and quality assured by the standards set in Good Agricultural Practices (GAP) and awarded palm oil sustainability certification such as MSPO.

Presently, the smallholders agree to join cooperative and sell their oil palm FFB through the cooperatives, the sale of FFB increased since the higher volume of FFB will enforce the bargaining power by the cooperative to the millers (Ador et al., 2016). Before joining the cooperatives, the harvested fruits or FFB were often put at the roadside to be picked by a middleman or dealer. There was no guarantee that the FFB could be delivered to the palm oil mills within 24 hours as required to 
sustain its quality (Hutabarat et al., 2018). In the worst case, the FFB was not sold and abandoned. Independent smallholders are usually affected by a low-price scale for their FFB at collection centres or weighbridges where they were paid lower by the middleman or dealers, who will then transport and sell their FFB to the palm oil mills. This is consistent with the theoretical expectation that higher bargaining power will be obtained by combining agricultural outputs together with the agricultural producers through a cooperative. With this regard, as suggested by Alho (2015), Grashuis and Su (2019) and Wassie et al. (2019), the revenue of the cooperative will increase as the bargaining power through cooperative is observed and resulted in the increment to the income of the smallholders which lead to the exceptional performance of oil palm cooperatives.

The cooperative thus facilitates its members in adherence to this certification towards higher quality standard and productivity, which ultimately contribute to cooperative's performance. In terms of productivity or yield, palm oil has the highest yield of oil recorded at 3.42 tonnes/hectare as compared to yield of other edible oil such as sunflower (0.77), soybean (0.51), groundnut (0.48), and coconut (0.32) (MPI, 2019). Globally, palm oil is considered as the most produced (34.7\% out of 230.08 million tonnes) and consumed (34.1\% out of 227.48 million tonnes) oils and fats in 2018 (MPI, 2019; Yew et al., 2016). With this regard, Malaysia has been the second global producer of edible oil after Indonesia (MPI, 2019). Thus, in the context of oil palm cooperative, productivity or yield of its members' oil palm plantation is crucial to be considered as one of the cooperative performance dimensions as suggested by Grashuis and Ye (2019), and Chagwiza et al. (2016) that accentuated productivity is essential to measure agricultural cooperatives performance. Thus, oil palm cooperative performance is operationalised based on revenue, product quality, smallholder's income and productivity or yield.

\section{SOP Framework}

This study formulates the following conceptual framework of the oil palm cooperatives to determine whether the effect of SOP is positively influencing the cooperative performance. Following this line of reasoning and using the relevant cooperative and sustainability literature as a basis, the conceptual framework of SOP as well as its outcomes on performance is developed as exhibited in Figure 1. This conceptual framework has been made based upon several frameworks established by previous scholars. The conceptual framework shown in Figure 1 is the combination of the framework, as Reverte et al. (2016), Epstein and Roy (2001) and Göran Svensson and Wagner (2015) propose. 


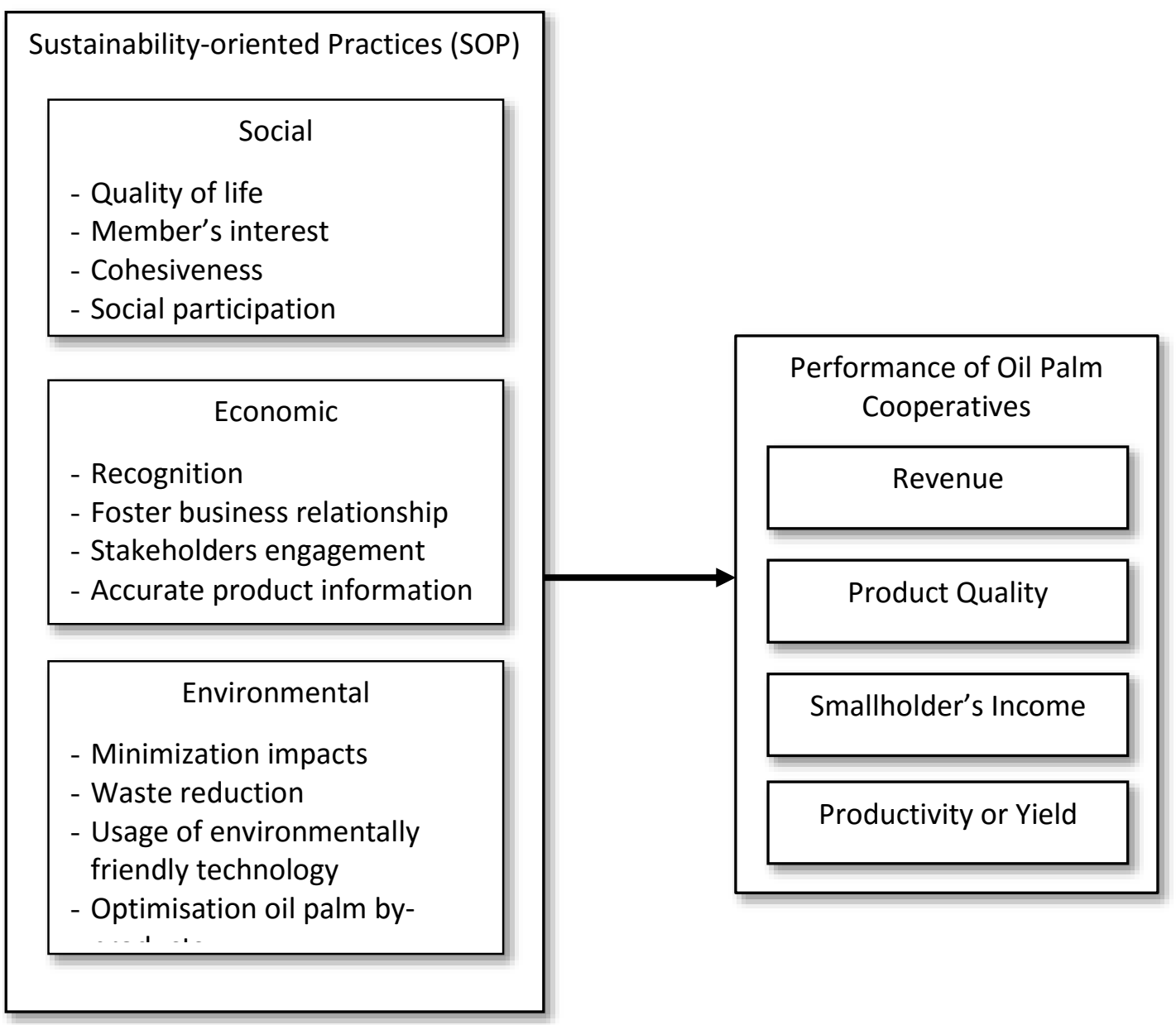

Figure 1: SOP Conceptual Framework of Oil Palm Cooperatives

Engaging in sustainability practices or activities is one of the primary mechanisms through which a business may foster and maintain stakeholder relationships. In tandem with the Stakeholder Theory by Freeman (1984); Aziz \& Mamat, (2018); Okwuraiwe, Ezenwaka, Mojekeh, Chiyem, (2018), it is conceptualised that the stakeholders' influence and trust will accumulate, when a business engages in socially responsible practices regularly. Furthermore, the Stakeholder Theory posits that when a business satisfies the social, and environmental needs of its key stakeholders, it will positively affect its financial performance, thus supporting the positive correlation on the relationship between social and environmental practices and financial performance (Donaldson \& Preston, 1995).

Consequently, the identification and disclosure of SOP that benefits the cooperative members while ensuring the governance practices that legitimise its conduct among its stakeholders are crucial for its superior performance. In other words, SOP requires acceptance from all the stakeholders in creating positive financial ends or improving the long-term financial performance (Epstein \& Roy, 2001; Schaltegger et al., 2017). Given the Stakeholder Theory and sustainability literature share a lot of similar ideas, the Stakeholder Theory can be purposefully applied in the context of sustainability 
(Hörisch et al., 2014; Schaltegger et al., 2017). Thus, the Stakeholder Theory is decisively underpinned to the conceptual framework of this study.

\section{Conclusion}

A significant contribution of this study is to propose a framework between phenomenon and outcomes of SOP on oil palm cooperatives performance. The proposed framework represents a conceptualization about how these constructs linked together to influence cooperative performance given that the social, economic and environmental, create the catalyst for sustainability-orientation phenomenon, which subsequently affects cooperative performance. Theoretically, this study enriches the Stakeholder Theory, cooperative and sustainability literature by understanding the relationship between sustainability practices and the performance of oil palm cooperative. Also, the fact that SOP implementation may influences cooperative performance, and thus, it suggests SOP plays a vital role in cooperative's ability to be successful. The framework provides a novel perspective on the relationship between SOP and performance of oil palm cooperatives in Malaysia.

Practically, this framework is the initial step to predict the performance of oil palm cooperatives based upon their SOP implementation in helping the cooperators to structure business strategies and plan by integrating the economic, social and environmental aspects. Given the crucial need to confirm the framework to be feasible and useful, further study must proceed with advanced quantitative techniques which validates the framework, and to ensure its dimensions are adequate and sufficient to depict the sustainability practices in the operations of oil palm cooperatives. Nevertheless, this framework is not only limited to oil palm cooperatives but can also be extended to other agricultural cooperatives in considering the sustainable aspects towards higher performance.

It is affirmed that cooperative is still well-suited to address contemporary challenges, such as protecting the environment and generate income for marginalized and most deprived groups such as the smallholders. Indeed, the role of cooperative is paramount in the palm oil industry as well as in other relevant economic sectors because it is regarded as the third engine of economic growth after the private and public sector (Abdul Aris et al., 2018). Given this conceptual framework has initiated a vital exploration and refinement of the primary constructs in the context of oil palm cooperatives, it is necessary to extend this framework to include variables such as innovativeness and agricultural extension services that relevant to enhance cooperative performance as Brat et al. (2016), Kyazze et al. (2017) and Ofori et al. (2019) propose for future research. Even though a conceptual paper, we hope this study helps in contributing to the sustainability and cooperative literature for the reference of scholars as well as significant guidance to the cooperators and policymakers upon full completion of the research.

\section{Corresponding Author}

Zaifalaila Zakaria

Universiti Teknologi Mara (UiTM),

Department of Postgraduate and Professional Studies,

Faculty of Business and Management, 40450 Shah Alam, Selangor, Malaysia

Email: zaifalaila@outlook.my 
INTERNATIONAL JOURNAL OF ACADEMIC RESEARCH IN BUSINESS AND SOCIAL SCIENCES

Vol. 10, No. 1, Jan, 2020, E-ISSN: 2222-6990 @ 2020 HRMARS

\section{References}

'Aini, Y. M., Hafizah, H. A. K., \& Zuraini, Y. (2012). Factors Affecting Cooperatives' Performance in Relation to Strategic Planning and Members' Participation. Procedia - Social and Behavioral Sciences, 65, 100-105. https://doi.org/10.1016/j.sbspro.2012.11.098

A. S. A. Ferdous Alam, A. C. Er, \& Halima Begum. (2015). Malaysian oil palm industry: Prospect and problem. Journal of Food, Agriculture and Environment, 13(2), 143-148. Retrieved from https://www.researchgate.net/publication/281275048_Malaysian_oil_palm_industry_Prospec t_and_problem

Abazue, C. M., Er, A. C., Ferdous Alam, A. S. A., \& Begum, H. (2015). Oil Palm Smallholders and Its Sustainability Practices in Malaysia. Mediterranean Journal of Social Sciences, (December). https://doi.org/10.5901/mjss.2015.v6n6s4p482

Aris, A. N., Marzuki, M., Othman, R., Rahman, A. S., \& Ismail, H. N. (2018). Designing indicators for cooperative sustainability: the Malaysian perspective. Social Responsibility Journal, 14(1), 226248. https://doi.org/10.1108/SRJ-01-2017-0015

Ador, S. F., Siwar, C., \& Ghazali, R. (2016). A Review of Palm Oil Impact on Sustainability Dimension: SPOC Initiative for Independent Smallholders. International Journal of Agriculture, Forestry and Plantation, 2(feb.), 104-110.

Kushairi, A. D. (2017). Malaysian Oil Palm Industry Performance 2016 and Prospects for 2017. Palm Oil Economic \& Outlook Seminar 2017, (Red li), 6. Retrieved from http://www.mpob.gov.my/images/stories/pdf/2017/2017_Dr.KushairiPALMEROS2017.pdf

Alho, E. (2015). Farmers' self-reported value of cooperative membership: evidence from heterogeneous business and organization structures. Agricultural and Food Economics, 3(1), 23. https://doi.org/10.1186/s40100-015-0041-6

Altman, M. (2010). History and Theories of Cooperatives. International Encyclopedia of Civil Society Springer, New York, NY, (December), 563-570.

Benos, T., Kalogeras, N., Wetzels, M., Ruyter, K. de, \& Pennings, J. M. E. (2018). Harnessing a 'Currency Matrix' for Performance Measurement in Cooperatives: A Multi-Phased Study. Sustainability, 10(12), 4536. https://doi.org/10.3390/su10124536

Berry, D., \& Bell, M. P. (2018). Worker cooperatives: alternative governance for caring and precarious work. Equality, Diversity and Inclusion, 37(4), 376-391. https://doi.org/10.1108/EDI-02-20170027

Birchall, J. (2017). The Governance of Large Co-operative Businesses. Manchester. Retrieved from https://www.ica.coop/sites/default/files/publication-files/governance-report2017coopsukfinalweb-1823508697.pdf

Bocken, N. M. P., Short, S. W., Rana, P., \& Evans, S. (2014). A literature and practice review to develop sustainable business model archetypes. Journal of Cleaner Production. https://doi.org/10.1016/j.jclepro.2013.11.039

Brat, E., Martínez, I. B., \& Ouchene, N. (2016). Innovation: Priorities and Practices in Cooperatives. Alphonse and Dorimène Desjardins International Institute for Cooperatives - ADDIIC, (October). Retrieved from http://institutcoop.hec.ca/wp-content/uploads/2016/10/Innovation-prioritiespractices-cooperatives-2016-EN-web.pdf

Cai, R., Ma, W., \& Su, Y. (2016). Effects of member size and selective incentives of agricultural 
cooperatives on product quality. British Food Journal, 118(4), 858-870. https://doi.org/10.1108/BFJ-11-2015-0456

Cantele, S., \& Zardini, A. (2018). Is sustainability a competitive advantage for small businesses? An empirical analysis of possible mediators in the sustainability-financial performance relationship. Journal of Cleaner Production, 182, 166-176. https://doi.org/10.1016/j.jclepro.2018.02.016

Castilla-Polo, F., Gallardo-Vázquez, D., Sánchez-Hernández, M. I., \& Ruiz-Rodríguez, M. C. (2018). An empirical approach to analyse the reputation-performance linkage in agrifood cooperatives. Journal of Cleaner Production, 195, 163-175. https://doi.org/10.1016/j.jclepro.2018.05.210

Chagwiza, C., Muradian, R., \& Ruben, R. (2016). Cooperative membership and dairy performance among smallholders in Ethiopia. Food Policy, 59, 165-173.

https://doi.org/10.1016/j.foodpol.2016.01.008

Cheney, G., Santa Cruz, I., Peredo, A. M., \& Nazareno, E. (2014). Worker cooperatives as an organizational alternative: Challenges, achievements and promise in business governance and ownership. Organization. https://doi.org/10.1177/1350508414539784

CICOPA. (2017). Cooperatives and employment: Second global report 2017- Contribution of cooperatives to decent work in the changing world of work.

Cramb, R., \& Curry, G. N. (2012). Oil palm and rural livelihoods in the Asia-Pacific region: An overview. Asia Pacific Viewpoint, 53(3), 223-239. https://doi.org/10.1111/j.1467-8373.2012.01495.x

Cramb, R., \& McCarthy, J. F. (2017). The Oil Palm Complex Smallholders, Agribusiness and the State in Indonesia and Malaysia. (R. Cramb \& J. F. McCarthy, Eds.), NUS Press (First). Singapore: NUS Press Pte Ltd. Retrieved from http://www.jstor.org/stable/10.2307/j.ctv1xz0km.7

Dale, A., Duguid, F., Lamarca, M. G., Hough, P., Tyson, P., Foon, R., ... Herbert, Y. (2013). Cooperatives and Sustainability: An investigation into the relationship. Report International Co-Operative Alliance, 1-76.

Donaldson, T., \& Preston, L. E. (1995). Stakeholder theory: Concepts, evidence, and implications. Academy of Management Review.

DOSM. (2017). Department of Statistics Malaysia Official Portal. Retrieved November 11, 2018, from https://www.dosm.gov.my/v1/index.php?r=column/cthemeByCat\&cat=153\&bul_id=UXFINUw xaUVJNUFqVG5qYmtXaWRRUT09\&menu_id=TE5CRUZCblh4ZTZMODZIbmk2aWRRQT09

Duguid, F., Lamarca, M. G., Hough, P., Tyson, P., Foon, R., Newell, R., ... Jeremy Murphy. (2013). Cooperatives and sustainability: An investigation into the relationship. Retrieved from http://www.ssg.coophttp//ica.coop

Elkington, J. (1998). Cannibals with forks. The triple bottom line of 21st century business. New Society Publishers. https://doi.org/0865713928

Epstein, M. J., \& Roy, M. J. (2001). Sustainability in action: Identifying and measuring the key performance drivers. Long Range Planning, 34(5), 585-604. https://doi.org/10.1016/S00246301(01)00084-X

Eriksson, D., \& Svensson, G. (2016). A balance model of theoretical sustainability - framework and propositions. Corporate Governance (Bingley), 16(1), 21-34. https://doi.org/10.1108/CG-012015-0006

Errasti, A., Bretos, I., \& Nunez, A. (2017). The Viability of Cooperatives: The Fall of the Mondragon Cooperative Fagor. Review of Radical Political Economics, 49(2), 181-197. 
INTERNATIONAL JOURNAL OF ACADEMIC RESEARCH IN BUSINESS AND SOCIAL SCIENCES

Vol. 10, No. 1, Jan, 2020, E-ISSN: 2222-6990 @ 2020 HRMARS

https://doi.org/10.1177/0486613416666533

Esim, S. (2017). Co-Operatives and the Sustainable Development Goals. Retrieved from www.ilo.org/coop

Fischer, E., \& Qaim, M. (2012). Linking Smallholders to Markets: Determinants and Impacts of Farmer Collective Action in Kenya. World Development, 40(6), 1255-1268.

https://doi.org/10.1016/j.worlddev.2011.11.018

Freeman, R. E. (1984). The Stakeholder Approach. In Strategic Management (pp. 1-2). Cambridge: Cambridge University Press. https://doi.org/10.1017/CBO9781139192675.003

Galpin, T., Whittington, J. L., \& Bell, G. (2015). Is your sustainability strategy sustainable? Creating a culture of sustainability. Corporate Governance (Bingley), 15(1), 1-17.

https://doi.org/10.1108/CG-01-2013-0004

Gan, P. Y., \& Li, Z. D. (2014). Econometric study on Malaysia's palm oil position in the world market to 2035. Renewable and Sustainable Energy Reviews, 39(June), 740-747.

https://doi.org/10.1016/j.rser.2014.07.059

Gao, J. (2010). The evolution of business sustainability: Historical trajectory and structural relationships. Dissertation Abstracts International Section A: Humanities and Social Sciences. Retrieved

from

http://search.proquest.com/docview/622192853?accountid=11162\%5Cnhttp://www.ub.gu.se /dynamiskt/cgi-bin/link_resolver/link_resolver.cgi?url_ver=Z39.88-

2004\&rft_val_fmt=info:ofi/fmt:kev:mtx:dissertation\&genre=dissertations+\%26+theses\&sid=Pr oQ:PsycINFO\&atitle

Ghalem, Â., Chafik, O., Chroqui, R., \& Alami, S. EL. (2016). Performance: A concept to define. Unpublished, (May 2017). https://doi.org/10.13140/rg.2.2.24800.28165

Giacomini, D., Chiaf, E., \& Mazzoleni, M. B. (2017). How to Measure Performance in Cooperatives? (pp. 343-361). Researchgate. https://doi.org/10.4018/978-1-5225-0731-4.ch016

Grashuis, J. (2017). Branding by U.S. Farmer Cooperatives: An empirical study of trademark ownership. Journal of Co-Operative Organization and Management, 5(2), 57-64. https://doi.org/10.1016/j.jcom.2017.09.002

Grashuis, J. (2018). A quantile regression analysis of farmer cooperative performance. Agricultural Finance Review, 78(1), 65-82. https://doi.org/10.1108/AFR-05-2017-0031

Grashuis, J., \& Su, Y. (2019). A Review of the Empirical Literature on Farmer Cooperatives: Performance, Ownership, Governance, Finance, and Member Attitude. Annals of Public and Cooperative Economics, 90(1), 77-102. https://doi.org/10.1111/apce.12205

Grüning, M. (2002). Ansätze zum Performance Measurement. In Performance-MeasurementSysteme (pp. 21-65). Wiesbaden: Deutscher Universitätsverlag. https://doi.org/10.1007/978-3663-08089-3_3

Hammad Ahmad Khan, H., Yaacob, M. A., Abdullah, H., \& Abu Bakar Ah, S. H. (2016). Factors affecting performance of co-operatives in Malaysia. International Journal of Productivity and Performance Management, 65(5), 641-671. https://doi.org/10.1108/IJPPM-05-2014-0077

Helleno, A. L., de Moraes, A. J. I., Simon, A. T., \& Helleno, A. L. (2017). Integrating sustainability indicators and Lean Manufacturing to assess manufacturing processes: Application case studies in Brazilian industry. Journal of Cleaner Production. 
INTERNATIONAL JOURNAL OF ACADEMIC RESEARCH IN BUSINESS AND SOCIAL SCIENCES

Vol. 10, No. 1, Jan, 2020, E-ISSN: 2222-6990 @ 2020 HRMARS

https://doi.org/10.1016/j.jclepro.2016.12.072

Henao, R., Sarache, W., \& Gómez, I. (2019). Lean manufacturing and sustainable performance: Trends and future challenges. Journal of Cleaner Production, 208, 99-116.

https://doi.org/10.1016/j.jclepro.2018.10.116

Herbert, Y., Foon, R., \& Duguid, F. (2016). Sustainability Reporting for Co-operatives: A Guidebook. Brussels: International Co-operative Alliance. Retrieved from https://www.ica.coop/en/media/ library/publications/sustainability-reporting-co-operatives-guidebook

Høgevold, N. M., Svensson, G., Klopper, H. B., Wagner, B., Valera, J. C. S., Padin, C., ... Petzer, D. (2015). A triple bottom line construct and reasons for implementing sustainable business practices in companies and their business networks. Corporate Governance (Bingley), 15(4), 427-443. https://doi.org/10.1108/CG-11-2014-0134

Hörisch, J., Freeman, R. E., \& Schaltegger, S. (2014). Applying Stakeholder Theory in Sustainability Management: Links, Similarities, Dissimilarities, and a Conceptual Framework. Organization and Environment. https://doi.org/10.1177/1086026614535786

Hutabarat, S., Slingerland, M., \& Dries, L. (2019). Explaining the “Certification Gap" for Different Types of Oil Palm Smallholders in Riau Province, Indonesia. The Journal of Environment \& Development, 28(3), 253-281. https://doi.org/10.1177/1070496519854505

Hutabarat, S., Slingerland, M., Rietberg, P., \& Dries, L. (2018). Costs and benefits of certification of independent oil palm smallholders in Indonesia. International Food and Agribusiness Management Review, 21(6), 681-700. https://doi.org/10.22434/IFAMR2016.0162

ICA. (2018a). Home I International Cooperative Alliance - Asia and Pacific. Retrieved July 3, 2019, from http://ica-ap.coop/

ICA. (2018b). What is a cooperative? Retrieved October 19, 2018, from https://www.ica.coop/en

ICA. (2019). Facts and figures / ICA. Brussels. Retrieved from https://www.ica.coop/en/cooperatives/facts-and-figures

ILO and ICA. (2015). Cooperatives and the Sustainable Development Goals: A Contribution to the Post-2015 Development Debate A Policy Brief. International Labour Organization: International Cooperative Alliance, 1-16. Retrieved from www.ica.coop

Jaabi, A. (2019, June 11). Championing palm oil's cause | New Straits Times | Malaysia General Business Sports and Lifestyle News. News Straits Times. Retrieved from https://www.nst.com.my/opinion/columnists/2019/06/495306/championing-palm-oils-cause

Jensen-Auvermann, T., Adams, I., \& Doluschitz, R. (2018). Trust-Factors that have an impact on the interrelations between members and employees in rural cooperatives. Journal of Co-Operative Organization and Management, 6(2), 100-110. https://doi.org/10.1016/j.jcom.2018.09.001

Karlsson, N. P. E., Laurell, H., Lindgren, J., Pehrsson, T., Andersson, S., \& Svensson, G. (2018). A crosscountry comparison and validation of firms' stakeholder considerations in sustainable business practices. Corporate Governance (Bingley), 18(3), 408-424. https://doi.org/10.1108/CG-072017-0131

Kontogeorgos, A. (2012). Brands, quality badges and agricultural cooperatives: How can they coexist? TQM Journal, 24(1), 72-82. https://doi.org/10.1108/17542731211191230

Kumaran, S. (2019). The Dynamics for Mandatory MSPO Certification Scheme to be Successfully Implemented. Journal of Oil Palm, Environment and Health (JOPEH), 10(0). 
INTERNATIONAL JOURNAL OF ACADEMIC RESEARCH IN BUSINESS AND SOCIAL SCIENCES

Vol. 10, No. 1, Jan, 2020, E-ISSN: 2222-6990 @ 2020 HRMARS

https://doi.org/10.5366/jope.2019.01

Kushairi, A., Loh, S. K., Azman, I., Hishamuddin, E., Ong-Abdullah, M., Izuddin, Z. B. M. N., ... Parveez, G. K. A. (2018). Oil palm economic performance in Malaysia and R\&D progress in 2017. Journal of Oil Palm Research, 30(2), 163-195. https://doi.org/10.21894/jopr.2018.0030

Kyazze, L. M., Nkote, I. N., \& Wakaisuka-Isingoma, J. (2017). Cooperative governance and social performance of cooperative societies. Cogent Business and Management, 4(1), 1-14. https://doi.org/10.1080/23311975.2017.1284391

Laurell, H., Karlsson, N. P. E., Lindgren, J., Andersson, S., \& Svensson, G. (2018). Re-testing and validating a triple bottom line dominant logic for business sustainability. Management of Environmental Quality: An International Journal. https://doi.org/10.1108/MEQ-02-2018-0024

Ma, W., \& Abdulai, A. (2016). Does cooperative membership improve household welfare? Evidence from apple farmers in China. Food Policy, 58, 94-102. https://doi.org/10.1016/j.foodpol.2015.12.002

Martens, K., Kunz, Y., Rosyani, I., \& Faust, H. (2019). Environmental Governance Meets Reality: A Micro-Scale Perspective on Sustainability Certification Schemes for Oil Palm Smallholders in Jambi, Sumatra. Society \& Natural Resources, 1-17. https://doi.org/10.1080/08941920.2019.1674436

Martins, F. S., \& Lucato, W. C. (2018). Structural production factors' impact on the financial performance of agribusiness cooperatives in Brazil. International Journal of Operations and Production Management (Vol. 38). https://doi.org/10.1108/IJOPM-10-2015-0637

Masuku, T. ., Masuku, M. ., \& Mutangira, J. P. . (2016). Performance of Multi-Purpose Cooperatives in the Shiselweni Region of Swaziland. International Journal of Sustainable Agricultural Research, 3(4), 58-71. https://doi.org/10.18488/journal.70/2016.3.4/70.4.58.71

Mathuva, D. M., \& Kiweu, J. M. (2016). Cooperative social and environmental disclosure and financial performance of savings and credit cooperatives in Kenya. Advances in Accounting, 35, 197-206. https://doi.org/10.1016/j.adiac.2016.09.002

MPI. (2019). Data Sets for Agricommodities Industry in Malaysia. Putrajaya: Ministry of Primary Industries. Retrieved from

http://www.data.gov.my/data/en_US/dataset?organization=ministry-of-plantation-industriesand-commodities

MPOC. (2019). ABOUT - The Oil Palm. Retrieved March 5, 2019, from http://theoilpalm.org/about/

MPOCC. (2019). MSPO Certified Areas. Kuala Lumpur. Retrieved from https://www.mpocc.org.my/certified-areas

Mura, M., Longo, M., Micheli, P., \& Bolzani, D. (2018). The Evolution of Sustainability Measurement Research. International Journal of Management Reviews, 20(3), 661-695. https://doi.org/10.1111/ijmr.12179

Nambiappan, B., Ismail, A., Hashim, N., Ismail, N., Shahari, D. N., Idris, N. A. N., ... Kushairi, A. (2018). Malaysia: 100 years of resilient palm oil economic performance. Journal of Oil Palm Research. https://doi.org/10.21894/jopr.2018.0014

Nesadurai, H. E. S. (2019). Transnational Private Governance as a Developmental Driver in Southeast Asia: The Case of Sustainable Palm Oil Standards in Indonesia and Malaysia. Journal of Development Studies, 55(9), 1892-1908. https://doi.org/10.1080/00220388.2018.1536262 
INTERNATIONAL JOURNAL OF ACADEMIC RESEARCH IN BUSINESS AND SOCIAL SCIENCES

Vol. 10, No. 1, Jan, 2020, E-ISSN: 2222-6990 @ 2020 HRMARS

Nurhazani, M. S., Azlan, Z. A., \& Baharin, K. A. M. (2016). Investigating board of directors ' perceptions on corporate governance practice in cooperatives. International Journal of Contemporary Applied Sciences, 3(1), 265-289. Retrieved from www.ijcas.net

Ofori, E., Sampson, G. S., \& Vipham, J. (2019). The effects of agricultural cooperatives on smallholder livelihoods and agricultural performance in Cambodia. Natural Resources Forum, 43(4), 218229. https://doi.org/10.1111/1477-8947.12180

Omar, W., Jaafar, N. C., \& Mansor, N. H. (2012). Smallholder Palm Oil Cluster: Sharing MPOB 's Experience By Definition of Smallholder. Kuala Lumpur. Retrieved from https://www.rt10.rspo.org/ckfinder/userfiles/files/PCPM2_4 Tn Hj Wahid Omar Presentation .pdf

Othman, A., Mansor, N., \& Kari, F. (2014). Assessing the performance of co-operatives in Malaysia: an analysis of co-operative groups using a data envelopment analysis approach. Asia Pacific Business Review, 20(3), 484-505. https://doi.org/10.1080/13602381.2014.933065

Owens, T., Hoddinott, J., \& Kinsey, B. (2003). The Impact of Agricultural Extension on Farm Production in Resettlement Areas of Zimbabwe. Economic Development and Cultural Change, 51(2), 337357. https://doi.org/10.1086/346113

Padin, C., Ferro, C., Wagner, B., Valera, J. C. S., Høgevold, N. M., \& Svensson, G. (2016). Validating a triple bottom line construct and reasons for implementing sustainable business practices in companies and their business networks. Corporate Governance (Bingley), 16(5), 849-865. https://doi.org/10.1108/CG-12-2015-0163

Parris, T. M., \& Kates, R. W. (2003). Characterising and Measuring Sustainable Development. Annual Review of Environment and Resources, 28(1), 559-586. https://doi.org/10.1146/annurev.energy.28.050302.105551

Peterman, A., Quisumbing, A., Behrman, J., \& Nkonya, E. (2011). Understanding the Complexities Surrounding Gender Differences in Agricultural Productivity in Nigeria and Uganda. Journal of Development Studies, 47(10), 1482-1509. https://doi.org/10.1080/00220388.2010.536222

Pletcher, J. (1991). Regulation with growth: The political economy of palm oil in Malaysia. World Development. https://doi.org/10.1016/0305-750X(91)90198-Q

PMO. (2018). [Speech text] Dr Mahathir at 73rd UN General Assembly | New Straits Times | Malaysia General Business Sports and Lifestyle News. New Straits Times Malaysia. Prime Minister Office Malaysia. Retrieved from https://www.nst.com.my/news/nation/2018/09/415941/speechtext-dr-mahathir-73rd-un-general-assembly

Porter, M. E., \& Linde, C. V. D. (1995). Toward a New Conception of the Environment-Competitiveness Relationship. Journal of Economic Perspectives, 9(4), 97-118.

https://doi.org/10.1257/jep.9.4.97

Pye, O. (2018). Commodifying sustainability: Development, nature and politics in the palm oil industry. World Development. https://doi.org/10.1016/j.worlddev.2018.02.014

Ragasa, C., \& Mazunda, J. (2018). The impact of agricultural extension services in the context of a heavily subsidized input system: The case of Malawi. World Development, 105, 25-47. https://doi.org/10.1016/j.worlddev.2017.12.004

Reverte, C., Gómez-Melero, E., \& Cegarra-Navarro, J. G. (2016). The influence of corporate social responsibility practices on organizational performance: Evidence from Eco-Responsible Spanish 
INTERNATIONAL JOURNAL OF ACADEMIC RESEARCH IN BUSINESS AND SOCIAL SCIENCES

Vol. 10, No. 1, Jan, 2020, E-ISSN: 2222-6990 @ 2020 HRMARS

firms. Journal of Cleaner Production, 112, 2870-2884.

https://doi.org/10.1016/j.jclepro.2015.09.128

Riva, E., \& Garavaglia, E. (2016). The sustainability and political agency of social cooperatives in Italy during the great recession. International Journal of Sociology and Social Policy, 36(7-8), 435455. https://doi.org/10.1108/IJSSP-01-2016-0005

Rival, A., \& Levang, P. (2014). Palms of controversies: Oil palm and development challenges. Palms of controversies: Oil palm and development challenges. https://doi.org/10.17528/cifor/004860

Saleh, N. M., \& Hamzah, N. (2017). Co-operative governance and the public interest: Between control and autonomy. Jurnal Pengurusan, 51(2017), 209-224.

Sallehhuddin, A., Said, A. M. A., Hasmanto, N., Mustafa, M. A., Jais, M., Samsudin, A., ... Ismail, H. (2017). Crafting Preliminary Model for Mosque Cooperatives' Antecedents of Performance. Asian Social Science, 13(2), 116. https://doi.org/10.5539/ass.v13n2p116

Schaltegger, S., Hörisch, J., \& Freeman, R. E. (2017). Business Cases for Sustainability: A Stakeholder Theory Perspective. Organization \& Environment, 108602661772288.

https://doi.org/10.1177/1086026617722882

Shamsuddin, Z., Ismail, A. G., Mahmood, S., \& Abdullah, F. (2017). Determinants of Agricultural Cooperative Performance Using Financial Ratio. International Journal of Business and Technopreneurship, 7(3), 385-396.

Shamsuddin, Z., Mahmood, S., Ghazali, P. L., Salleh, F., \& Nawi, F. A. M. (2018). Indicators for Cooperative Performance Measurement. International Journal of Academic Research in Business and Social Sciences, 8(12), 577-585. https://doi.org/10.6007/IJARBSS/v8-i12/5056

Shaufique, S. F. (2017). Independent smallholders in the global palm oil value chain. A Case Study of Malaysia.

SKM. (2014). Kajian Semula Dasar Koperasi Negara 2011-2020. Kuala Lumpur.

Svensson, Göran, Ferro, C., Høgevold, N., Padin, C., Carlos Sosa Varela, J., \& Sarstedt, M. (2018). Framing the triple bottom line approach: Direct and mediation effects between economic, social and environmental elements. Journal of Cleaner Production, 197, 972-991. https://doi.org/10.1016/j.jclepro.2018.06.226

Svensson, Goran, Høgevold, N. M., Petzer, D., Padin, C., Ferro, C., Klopper, H., ... Wagner, B. (2016). Framing stakeholder considerations and business sustainability efforts: a construct, its dimensions and items. Journal of Business \& Industrial Marketing, 31(2), 287-300. https://doi.org/10.1108/JBIM-05-2014-0094

Svensson, Göran, \& Wagner, B. (2015). Implementing and managing economic, social and environmental efforts of business sustainability propositions for measurement and structural models. Management of Environmental Quality: An International Journal, 26(2), 195-213. https://doi.org/10.1108/MEQ-09-2013-0099

Tarmuji, I., Maelah, R., \& Tarmuji, N. H. (2016). The Impact of Environmental, Social and Governance Practices (ESG) on Economic Performance: Evidence from ESG Score. International Journal of Trade, Economics and Finance, 7(3), 67-74. https://doi.org/10.18178/ijtef.2016.7.3.501

Tayleur, C., Balmford, A., Buchanan, G. M., Butchart, S. H. M., Corlet Walker, C., Ducharme, H., ... Phalan, B. (2018). Where are commodity crops certified, and what does it mean for conservation and poverty alleviation? Biological Conservation, 217, 36-46. 
https://doi.org/10.1016/j.biocon.2017.09.024

Tuominen, P., Syrjä, P., Sjögrén, H., \& Tuominen, T. (2017). CSR activities in consumer co-operatives: Exploring the case of Finnish S Group co-operatives based on board reporting. Journal of CoOperative Organization and Management, 5(2), 108-117.

https://doi.org/10.1016/j.jcom.2017.10.002

UN. (2017). Cooperatives in Social Development: Report of the Secretary-General (Vol. 12080). New York. Retrieved from https://documents-dds-

ny.un.org/doc/UNDOC/GEN/N17/217/92/PDF/N1721792.pdf?OpenElement

Upward, A., \& Jones, P. (2016). An Ontology for Strongly Sustainable Business Models. Organization \& Environment, 29(1), 97-123. https://doi.org/10.1177/1086026615592933

Wahid, M. B. (2009). Palm Oil : Nature 's Gift to Malaysia and Malaysia's Gift to the World. Oil Palm Industry Economic Journal, 9(1).

Wassie, S. B., Kusakari, H., \& Masahiro, S. (2019). Inclusiveness and effectiveness of agricultural cooperatives: recent evidence from Ethiopia. International Journal of Social Economics, 46(5), 614-630. https://doi.org/10.1108/IJSE-07-2018-0340

Yacob, Y., Ali, J. K., Roslin, R., \& Ting, H. (2018). The relationships between member participation, trust, Behavioural loyalty, and the moderating effect of ethnicity: An explanatory study of value co-creation among cooperative members in Sarawak. International Journal of Business and Society, 19(2), 505-522.

Yew, V. W. C., Awang, J. B., Manaf, A. A., Ramli, Z., \& Nambiappan, B. (2016). The sustainability of oil palm industry in Malaysia: A comprehensive review. International Journal of Economic Perspectives. International Economic Society Ltd. Retrieved from https://ukm.pure.elsevier.com/en/publications/the-sustainability-of-oil-palm-industry-inmalaysia-a-comprehensi

Abdullahi, A., Rouyan, N. B. M., Noor, S. S. binti M., \& Halim, Z. bin A. (2018). Sentence Construction Errors among Malay Arabic Learners at Universiti Sultan Zainal Abidin. International Journal of Academic Research in Business and Social Sciences, 8(6), 953-966.

Ohaka, J., Ogaluzor, O. I. (2018). Corporate Social Responsibility Accounting and the Effect of Donations on Profitability of Oil and Gas Companies in Nigeria, International Journal of Academic Research in Accounting, Finance and Management Sciences 8 (3): 265-276. 